Greece \& Rome, Vol. 56, No. 2, (C) The Classical Association, 2009. All rights reserved doi:10.1017/S0017383509990015

\title{
HISTORY MEETS FICTION IN DOCTOR WHO, 'THE FIRES OF POMPEII': A BBC RECEPTION OF ANCIENT ROME ON SCREEN AND ONLINE*
}

\author{
By FIONA HOBDEN
}

'Ancient Rome!' The door of the iconic police box squeaks open. The camera pans, following a dark-haired man as he emerges, pushes through a curtained doorway, and, with a glint in his eye, glee in his smile, and a touch of London in his voice, announces their destination to his redhead companion. So begins 'The Fires of Pompeii', the second episode in the fourth season of the current BBC (British Broadcasting Corporation) science-fiction drama Doctor Who. And so, no doubt, began the scribbling of pens on notebooks, as classicists who examine popular receptions of ancient Greece and Rome recognized a fresh opportunity to explore the dynamics of modern engagements with the classical world. At the time of broadcast, I was ensconced in my Liverpool office, writing the final lecture of a new undergraduate module devoted to Roman society. The topic was 'Receptions of Roman Life'. My plan was to contrast depictions of Roman life in different media from distinct periods to encourage our students to recognize how modern reconstructions of Roman society are variously informed by questions of authority, genre, and cultural contexts. Serendipitously, 'The Fires of Pompeii' provided an engaging contemporary reception of the Roman world on television.

Although 'The Fires of Pompeii' was initially broadcast on BBC1 on 12 April 2008 in its usual Saturday evening slot, it was not merely a televisual event. Over the past year, broadcasters in the UK have embraced technology that enables audiences to access their programmes repeatedly via the World Wide Web for a limited period of time. Usually, these programmes are embedded within dedicated programme websites featuring additional information about the show. In the case of 'The Fires of Pompeii', the episode was nested among video interviews with and audio commentaries by the Doctor Who cast

\footnotetext{
* Thanks are due to Tom Harrison, David Montagnes, and Jo Paul for their conversation and encouragement during the writing of this paper.
} 
and production team, and other behind-the-scenes features. The convergence of television and internet, or the 'blending of platforms' to use the technical jargon - through broadcasters' websites mirrors a strategy utilized extensively by the film industry to promote its cinematic products. As for film, websites are designed to secure audiences and enable the medium - in this instance television - to dominate the rival internet. ${ }^{1}$ But they also generate new interactive appreciations of the televisual product. This is especially pronounced for Doctor Who because, since the series was reprised in 2005, its producers have consciously pursued a multi-platform approach. New technologies, including the mobile phone, podcasting, interactive television, and the World Wide Web, create opportunities for 'transmedia storytelling' that encourage audience participation with Doctor Who across platforms. ${ }^{2}$ By interacting with any part of the officially sanctioned output, the user enriches his or her Doctor Who experience, including appreciation of the television series. Thus, 'The Fires of Pompeii', and hence its Roman receptions, cannot be read in isolation from the episode's BBC website. The Doctor opens the TARDIS door to ancient Rome, but that Rome is open to analysis, deconstruction, and re-evaluation by the inquisitive online audience.

My reading of Doctor Who's Rome prioritizes the interaction between the television event, 'The Fires of Pompeii', and the accompanying website, and so contributes towards the burgeoning discussion of antiquity in popular culture. I begin with the episode, exploring how history and fiction collide to present a city and society suitable for the programme and the immediate story. I then examine how the Roman world is reinforced as both a historical and a fictionalized space by features hosted on the Doctor Who website. I demonstrate, first, how popular (televisual and science-fiction) imaginings of the Roman world play with history constructively: 'The Fires of Pompeii' demands an identifiable past, even though its reality and historicity are bound up in televisual traditions as much as external

1 Some of the strategies by which this is achieved are discussed by E. Sapiera, 'From Couch Potatoes to Cybernauts? The Expanding Notion of the Audience on TV Channels' Websites', New Media E Society 6 (2004), 155-72. This convergence is part of a wider processual shift that impacts on how television and other media are produced and consumed: see H. Jenkins, Convergence Culture. Where Old and New Media Collide (New York and London, 2006).

2 See N. Perryman, 'Doctor Who and the Convergence of Media: A Case Study in "Transmedia Storytelling", Convergence 14 (2008), 21-39. Perryman offers a reminder that, with a presence on television and radio, in annuals, magazines, and comics, and on video and the cinema screen, Doctor Who has been a multi-platform phenomenon for much of its existence $(22-5)$. 
historical narratives. ${ }^{3}$ Secondly, the convergence of television and the internet generates synergistic receptions of ancient Rome. With so many unofficial websites, discussion forums, and social networking sites dedicated to Doctor Who, it would be impossible to unpack all potential cyber-contexts for reading 'The Fires of Pompeii', but the official BBC website alone supports this analysis. Thirdly, contemporary receptions can foster a critical appreciation of history in their audience. Contrary to popular conceptions and student expectations, ancient Rome was not a real place we could visit, if only we had a time-machine (or TARDIS). Rather it is the malleable, increasingly nuanced, and ever-changing product of our imaginative engagement with surviving sources: written and visual texts that discuss or represent the ancient world. Reading 'The Fires of Pompeii' in its multi-media context, where the processes of Rome's construction as a space and society are laid bare, fosters understanding of the artificial, constructed, and contested nature of the past. From here, we can understand our own processes of reconstruction as historians, identifying the concerns that inform ancient sources and appreciating the fabricated nature of our 'Rome'.

\section{'It's so Roman ...': televisual intertextuality and historical fictions}

When Donna Noble, the Doctor's red-haired companion, struggles to assimilate her new surroundings, her first responses is ' $\mathrm{Oh}$ my god, it's so ... it's so Roman'. And indeed it is. As orientalizing strains sound in the background, the camera follows the two protagonists along narrow streets filled with a multi-racial mix of women and children in colourful clothes, Roman centurions, graffitied walls, and amphorae on market stalls. This is the Rome of modern scholarship: a multi-cultural cosmopolitan capital, where shops and traders lined the streets, a place of dirt and grime. ${ }^{4}$ It is also the Rome of the

${ }^{3}$ Although popular receptions of antiquity in cinema have become mainstays of academic investigation over the past decade, television and science fiction are two of the more neglected venues for reception studies: see G. Nisbet, Ancient Greece in Film and Popular Culture (Bristol, 2006), 137-40, for some explanations and potential pitfalls. A. J. Pomeroy, Then it was Destroyed by the Volcano. The Ancient World in Film and on Television (London, 2008), closes the divide between film and television, and examines the classical past in the science fiction genre more extensively. Further reflections on science fiction and classics are posted by Tony Keen on his blog, Memorabilia Antonina, <http://www.tonykeen.blogspot.com>, accessed 8 January 2009.

${ }_{4}^{4}$ See, for example, C. Edwards and G. Woolf (eds.), Rome the Cosmopolis (Cambridge, 2003). 
post-peplum cinematic tradition: the gritty city that replaced marble colonnades in A Funny Thing Happened on the Way to the Forum (1965), and the bustling, colourful cityscape of Gladiator (2000). ${ }^{5}$ But more precisely, visually and aurally, this is the city of Rome (2005-7), the historical drama produced jointly by the US television network HBO (Home Box Office) and the BBC. ${ }^{6}$ The external city shots of 'The Fires of Pompeii' and Rome were both filmed in the Cinecittà studios in Rome. ${ }^{7}$ The set and costumes in the opening scene are strikingly familiar to anyone who has watched the historical drama, especially its opening titles where the viewer is led through the city streets to the accompaniment of 'period' sounds: off-beat percussion, minor strings, and a discordant, quasi-Middle Eastern tune. ${ }^{8}$

${ }^{5}$ On the dirty city streets of A Funny Thing Happened on the Way to the Forum, see N. Cull, " Infamy! Infamy! They've all got it in for me!": Carry On Cleo and the British Camp Comedies of Ancient Rome', in S. R. Joshel, M. Malamud, and D. T. McGuire, Jr (eds.), Imperial Projections: Ancient Rome in Modern Popular Culture (Baltimore and London, 2001), 179-80. The deconstruction of the gleaming Rome of the sword-and-sandals epic was facilitated by Fellini-Satyricon (1969). In this film, the director Federico Fellini wanted 'to strip the image of ancient Rome of its cultural accretions': M. Wyke, Projecting the Past. Ancient Rome, Cinema and History (London, 1997), 190. The dissonant, disconcerting, and fantastical ancient city resonates with Fellini's broader filmic imaginings of Rome: see E. Theodorakopoulos, 'The Sites and Sights of Rome in Fellini's Films: "Not a Human Habitation but a Psychical Entity", in D. H. J. Larmour and D. Spencer (eds.), The Sites of Rome: Time, Space, Memory (Oxford, 2007), 353-84; and J. Paul, 'Rome Ruined and Fragmented: The Cinematic City in Fellini-Satyricon and Roma', in R. Wrigley (ed.), Cinematic Rome (Leicester, 2008), 109-20. Such unsettling of the cityscape permitted Gladiator to reconstruct ancient Rome anew. In addition to the bustling streets, "the new "real" Rome in Gladiator is a pastiche of a seventeenth-century Spanish fort on Malta (rebuilt by Napoleon in classical style), pictures of classical buildings all over Europe, and computer generated effects': S. R. Joshel, M. Malamud, and M. Wyke, 'Introduction', in Joshel, Malamud, and McGuire, 1; cf. M. Junkelmann, Hollywoods Traum von Rom. Gladiator und die Tradition des Monumentalfilms (Mainz, 2004), 293-8.

6 The grittiness of Rome's Rome was designed to replace earlier 'pastiche' approaches presumably like that of Gladiator - with an authentic depiction of the city. Its assumed association between dirt and realism is shared by the contemporary HBO drama Deadwood (2004-6), which fashions the Wild West townscape of the eponymous outlaw camp to similar ends. On both programmes, see J. de Groot, Consuming History. Historians and Heritage in Contemporary Popular Culture (London and New York, 2009), 199-200. Rome's bid for authenticity is discussed below (see also notes 9 and 39).

7 The sharing of sets by different productions is both a convenience and a commonplace: see Pomeroy (n. 3), 58. But it can also be used to deliberate effect: for example, Carry on Cleo (1963) mockingly recycled the costumes worn by Richard Burton, Elizabeth Taylor, et al in Cleopatra (1964): see Cull (n. 5), 168.

8 This creation of an ancient atmosphere through 'exotic' rhythms and sounds can be found in films throughout the twentieth century: see M. M. Winkler, Classical Myth and Culture in the Cinema (Oxford, 2001), 319-37, for whom Miklós Rózsa, the composer for the sword-and-sandal epic Quo Vadis (1951), was particularly influential in the creation of a Roman period sound. Note also that the scores for Victorian and Edwardian toga dramas used 'Roman music' that included quasi-orientalizing, themes such as Gounod's Ballet from The Queen of Sheba (1862): see K. Preston, 'The Music of Toga Drama', in D. Mayer (ed.), Playing out the Empire. Ben-Hur and Other Toga Plays and Films, 1883-1908. A Critical Anthology (Oxford, 1994), 28. 
Thus, when the Doctor steps out of the TARDIS, he enters the Rome of our cinematic and televisual imagination. Donna's wonder at being in this strange, ancient city becomes more enjoyable through the recognition (hers and ours) that she is truly there. However, while Rome takes its high historical credentials seriously, Doctor Who has fun with its setting. ${ }^{9}$ On their stroll through the city, the pair encounter a Roman market trader who would be at home in the London-based BBC soap opera EastEnders (1985-present). When Donna approaches him to test her Latin skills, he leers in a friendly fashion and greets her with 'Allo sweetheart, what can I get you my love?'. Later, when the Doctor confronts him about selling the TARDIS, the trader reveals in a cheery cockney drawl, 'I got fifteen sestertii for it, lovely jubbly'. The mannerism, accent, and closing catch phrase, popularized by the market trader Del Boy in the BBC comedy series Only Fools and Horses (1981-2003) and heard on the streets of London today, gives ancient Rome a contemporary spin. The joke continues when Donna inquires whether their clothes will look a bit odd. The Doctor replies, 'Naaah, Ancient Rome, anything goes. It's like Soho, only bigger.' This playful mix of antiquarianism and modernity reinforces the foreignness and familiarity of the ancient city: the cityscape is alien, yet it is a reassuringly 'Roman' space, and a present-day London too. The joke, however, is bigger still. Like any good tourist today, the Doctor looks forward to visiting the Colosseum, Pantheon, and Circus Maximus. Of course, these monuments are missing because, as they deduce when a smoking volcano appears on the horizon, Donna and the Doctor are really in Pompeii.

This Rome that is both familiar and strange, and in fact is no Rome at all, is thoroughly in keeping with the Doctor Who brief. The Doctor is a Time Lord from the planet Gallifrey who travels across time and space in his TARDIS, a 'Time And Relative Dimensions In Space' machine. As the writer James Moran remarks, Doctor Who 'can go anywhere, any time in space'. ${ }^{10}$ But, in fact, although some of the worlds the Doctor visits are graphically and viscerally alien, since the programme was reprised the Time Lord Doctor has travelled frequently into the past, especially the past of our shared imaginary: among other locations, Victorian Cardiff ('The Unquiet Dead'),

${ }^{9}$ See H. Haynes, 'Rome's Opening Titles: Triumph, Spectacle, and Desire', in M. S. Cyrino (ed.), Rome Season One. History Makes Television (Oxford, 2008), 49-60, on the dynamics of realism in that series.

10 'Writing the Episode': <http://www.bbc.co.uk/doctorwho/s4/episodes/S4_02> ('Video' menu), accessed 8 January 2009. 
London during the Blitz ('The Empty Child'/'The Doctor Dances'), and Shakespeare's London ('The Shakespeare Code') have all featured. ${ }^{11}$ In these episodes, the drama evolves through the intervention of the alien into the known. Gas creatures interrupt a public reading by Charles Dickens when they seek to open a portal to Earth in Cardiff; Londoners are turned into gas-masked zombies when a space ambulance crash-lands during the Blitz; and a race of witch-like aliens attempts to take over the earth by inspiring Shakespeare to write the lost comedy, Love's Labour's Won. Each time, the human race faces ultimate destruction; only the Doctor can save the day. This same tension and plot underlie our episode. Alien lava-monsters called Pyroviles lurk in Vesuvius, waiting to burst free and conquer the planet. The adoption of a recognizable setting that, like the Victorian city, World War II, and Shakespearean London, is part of our collective history (the history we Brits are weaned on at school and through television) facilitates this basic narrative. ${ }^{12}$ The familiarity of Rome/Pompeii prompts an emotional engagement with the predicament that besets our cultural ancestors, of an alien threat lurking unseen behind their daily lives. ${ }^{13}$

The Romans at the centre of the action operate similarly. They are the family of Caecilius, 'the big man on Foss Street' from whom Donna and the Doctor must reclaim the TARDIS. Students of the Cambridge Latin Course, taught in British schools for almost forty years, are well acquainted with them. ${ }^{14}$ Caecilius, his wife Metella, and son Quintus are introduced in Unit 1, Stage 1 and provide the narrative focus until, in Stage 12, Vesuvius explodes. The family with the addition of a daughter Evelina, whose visions alert the Doctor to an alien presence - were introduced on the instructions of

11 Keen (n. 3), in 'Doctor Who: The Fires of Pompeii' (12 April 2008), attributes this interest in Earth's history to a conscious decision to avoid far-flung planets in the current seasons (accessed 8 January 2009).

12 For the role television itself plays in creating our sense of history, it is interesting to note that three out of the four periods portrayed in the episodes mentioned so far have been the subject of BBC documentaries presented by Adam Hart-Davis that explicitly connect the present to the past by investigation: What the Romans did for us (2000), What the Victorians did for us (2001), and What the Tudors and Stuarts did for us (2002). Note also that Doctor Who was originally envisaged as helping young viewers learn about history and science: P. Wright, 'Intertextuality, Generic Shift and Ideological Transformation in the Internationalising of Doctor Who', Foundation: The International Review of Science Fiction 92 (2004), 66.

${ }_{13}$ This accords with the preoccupations of the current series identified by G. Russell in Doctor Who. The Inside Story (London, 2006), 16: 'the urban settings to firmly place the show in the real world, and the monsters and menaces that affect real people with real emotions'. On the psychoanalytical power of this essential Doctor Who narrative, see S. Thornham and T. Purvis, Television Drama. Theories and Identities (Basingstoke, 2006), 103-4.

14 Cambridge Latin Course: Unit 1, fourth edition (Cambridge, 1998). 
the head writer and conceptual supremo Russell T. Davies. According to Moran, Davies was motivated by affection for the language course, and their inclusion is an in-joke for young Latin-learning viewers to enjoy. ${ }^{15}$ However, no further correspondences are developed. For example, the Cambridge Caecilius is a banker, but, for storytelling reasons, Doctor Who's Caecilius is a marble dealer: his latest commission, a marble circuit board, offers another indication of aliens in Pompeii. Moreover, the protagonists of the Cambridge Latin Course were drawn from the remains of Pompeii, where the house of Lucius Caecilius Iucundus stands on the Via Stabina. Yet scenes in Caecilius' home were shot in re-decorated sets from Rome: no attempt was made to fashion the house after the archaeological record. ${ }^{16}$ Thus, Caecilius' authenticity derives entirely from his Cambridge roots. For Moran and Davies, it is crucial that their characters are 'a real family': their plight lends a human perspective to that of Pompeiian residents, whose fate lies in the Doctor's hands. ${ }^{17}$ But their reality is grounded in fiction.

The interplay between authenticity and fictionality is underscored by the actors. Caecilius is the Italian-Scot Peter Capaldi, a man with a good 'Roman' visage; his son is played by another Celt with an Italian heritage, the Welsh actor François Pandolfo. ${ }^{18}$ And, as an alumna of Rome, Evelina (Francesca Fowler) is also recognizably 'Roman'. ${ }^{19}$ So Caecilius and his family are an odd hybrid of historicism and invention, sieved through the Cambridge Latin Course and BBC's Rome and refictionalized in 'The Fires of Pompeii'. This dynamic is strongest when the Doctor informs Caecilius, 'One day Pompeii will be found again in thousands of years, and everyone will remember you.' The depicted event is tied to the historical reality of excavation and rediscovery, but more pertinently to imaginative engagements with

15 Moran in 'Writing the Episode' (n. 10). This intertextuality was reciprocated by the Cambridge Latin Course. At the time of broadcast, Caecilius' new incarnation in Fires of Pompeii was marked on its website (<http://www.cambridgescp.com>, accessed 20 April 2008) with a direct link to the BBC 'Fires of Pompeii' website.

16 The Rome sets were repainted to give a splash of colour and make them feel alive: listen to associate designer James North in the 'Episode Commentary', <http://www.bbc.co.uk/ doctorwho/s4/episode/S4_02> ('Sounds' menu), accessed 8 January 2009.

17 Moran in 'Episode Commentary' (n. 16).

18 All the extras in the Pompeii street scenes were Italian: North in the 'Episode Commentary' (n. 16) remarks, 'It really helps actually, doesn't it? It gives it that authentic feel.'

19 Fowler's role in Rome is noted in the 'Fact File', <http://www.bbc.co.uk/doctorwho/ s4/episode/S4_02> ('Features' menu), accessed 8 January 2009. However, as she played the brothel-based prostitute Egeria (Season 1, Episode 6), her Romanness derives purely from her participation in the series, not from the character she depicted there. 
Pompeii by today's Latin students (and Doctor Who audiences), whose favourite family is spared death.

To further complicate the picture, despite their Roman costumes and home replete with atrium, Lares shrine, ancestor busts, and slaves, the Caecilius family is very much a modern one. Or, more accurately, it is a replica of the modern British sitcom family. ${ }^{20}$ Like all good sitcom families, it is mildly dysfunctional. ${ }^{21}$ The first family scene establishes Metella within the tradition of overbearing wife and mother, paralleled in BBC comedies such as Sorry! (1980-88), 2point4 Children (1991-99), and My Family (2000-present): she harangues her husband for his latest ridiculous enterprise (buying a useless piece of modern art, the TARDIS), chastises her son for his crude language, and snippily remarks that Evelina has made her proud at last. The henpecked husband, on the other hand, is eternally on the make with madcap schemes. ${ }^{22}$ His relationship with his children is equally stereotypical: he berates his hung-over son, and challenges Evelina's dress, to which she appropriately replies 'Don't start dad, it's what all the girls in Rome are wearing.' Quintus, in turn, behaves with the grace of a more refined Kevin the Teenager, the stroppy son who made his debut in the sketch show Harry Enfield's Television Programme (BBC, 1990). Thus, as individuals and in their relationships, the Caecilius family succumb to a variety of comic conventions. Just as Rome is recognizable via Rome, the televisual tradition generates familiarity.

Believability is essential to the 'social realism' of the sitcom genre, and Doctor Who is certainly a comic production. ${ }^{23}$ In 'The Fires of Pompeii', moreover, the believability of the family was essential to the episode brief, which required 'some scenes in the villa where they [the

20 The original reference point for Davies was, in fact, the Roman family in the comic book Asterix and the Laurel Wreath (Leicester, 1974), indicating that 'a likeable, ineffectual dad, a hapless son, [and] a strong wife' belong to a wider comic tradition. See R. T. Davies and B. Cook, Doctor Who. The Writer's Tale (London, 2008), 72 and 201, where it is revealed that Moran gave them their basic shape. Note that the Romanitas of Caecilius' family is of course compacted by Russell's original inspiration, even as it is developed within the televisual tradition.

${ }^{21}$ For B. Mills, Television Sitcom (London, 2005), 41, the dysfunctionality of core characters or 'family' and their relationships is a distinctive factor in the 'Britcom' (British sitcom): 'Britcom repeatedly focuses on characters who are incapable of communicating and for whom relationships and family are problematic and stifling'.

${ }^{22}$ This father type is also the product of an international sitcom tradition: see E. Scharrer, 'From Wise to Foolish: The Portrayal of the Sitcom Father, 1950s-1990s', fournal of Broadcasting and Electronic Media 45 (2001), 23-40.

${ }^{23}$ T. Lovell, 'A Genre of Social Disruption?', in J. Cook (ed.), Television Sitcom (London, 1982), 23. 
audience] get to know the people of Pompeii through that family'. ${ }^{24}$ The central question at the heart of the episode, introduced at the moment Donna realizes that they are in Pompeii on Volcano Day and played out until the final scenes, is: should the Doctor warn the inhabitants of their impending doom? To accompany the protagonists in their emotional crisis, the audience must understand the full horror that non-intervention will bring, and to understand that horror they must relate to Caecilius' family. In the end, the Doctor's conundrum is solved by the presence of the Pyroviles: because they intend to take over and thereby destroy the planet, he is forced to surrender Pompeii by igniting the volcano and destroying the aliens and the city. But the humanity of Caecilius' family and Donna's heartfelt pleading also encourage the Doctor to save them from annihilation. This in turn builds on a dramatic tension in the Doctor Who series: the alienness of the Doctor, the ancient Time Lord from Gallifrey, who repeatedly saves humanity from destruction, yet stands perpetually apart from it. $^{25}$ Additionally, it aids the development of the series. Donna's role as the Doctor's new companion is assured when he admits, 'You were right. Sometimes I need someone', and the two depart for new times and places.

In short, the townscape and family of 'The Fires of Pompeii' are strikingly Roman. The set and script construct a past that looks and sounds like ancient Rome, a Rome that emanates from visions of its urban and domestic space in classroom textbooks, television, and film. Its historicity is thus highly crafted and derivative. It is also inherently familiar: although distant in time and place, the city is like London, and its people are comprehensible to a British audience. Across the board, television and reality collide: the 'real' Rome/Pompeii is the BBC/HBO Rome, while the market trader and Caecilius' family belong firmly within the comic traditions of the BBC. Furthermore, the ancient world is driven by the needs of the immediate episode, informed by the Doctor Who genre in its current incarnation. Comic and dramatic elements combine to explore a moral dilemma, to enable the Doctor to fulfil his traditional saviour role, to advance the

24 Moran in 'Writing the Episode' (n. 10).

25 This aspect of his character is played with to various degrees in the Doctor's ten incarnations: see M. Hills, 'Doctor Who', in G. Creeber (ed.), Fifty Key Television Programmes (New York, 2004), 77. It is particularly important for the tenth Doctor, the protagonist of 'The Fires of Pompeii', 'who's much nimbler, who can turn on a sixpence more, who is more overtly compassionate, and empathetic and burdened with the responsibility of looking after all humanity' (Jane Tranter, BBC Controller of Drama Commissioning, cited by Russell [n. 13], 41-2). 
character development of Donna and the Doctor and their relationship, and to provide an impetus towards future episodes.

At two extremes, the Romanitas of the episode is both pronounced and vital (in the attention to physical detail and the dynamic of the story) and also irrelevant ('Rome' is just another destination where the Doctor can carry out his good work). ${ }^{26}$ This tension is amusingly expressed in the role allotted to the Lares ('household gods') and their shrine, the lararium. They appear in the first family scene: when Quintus apologizes to the household gods for swearing, he sprinkles water over a marble plaque sculpted with two figures on either side of a temple in relief. Such detail draws attention to a very Roman feature of family life. ${ }^{27}$ Yet it also anticipates the episode's closing joke. Relocated and rehabilitated, Quintus offers thanks to the household gods: the figures on the marble relief have morphed into Donna Noble and the Doctor, and the temple is now the TARDIS. Once again, the Roman setting is suborned into the Doctor Who story. As throughout, the historical setting is highly fictionalized, but without that historicity the fiction would not work.

\section{Exposing fictions and making history at the Doctor Who website}

This analysis of 'The Fires of Pompeii' could explore other reflections of the Roman world, or the episode's response to the Pompeian imaginary ${ }^{28}$ It could compare this present-day 'Rome' to the city visited by William Hartnell's Doctor in 'The Romans' (1965), or situate the episode more firmly within the Doctor Who repertoire, looking back at the Classic (1963-89) episodes and outwards to the various comics, novels, audio books, role-playing games and computer games centred on the concept. ${ }^{29}$ In the novels, the Doctor visits the Roman world at

${ }^{26}$ De Groot (n. 6), 204, is thus not entirely accurate when he claims that 'the past in Doctor Who is simply a backdrop to have the particular episodes' narrative projected onto rather than inextricably intertwined with the events unfolding'.

27 On worship of the Lares, see V. M. Warrior, Roman Religion (Cambridge, 2006), 13-14 and 28-33, with figs. 11, 20 and 23. For comparison, P. Zanker, Pompeii: Public and Private Life (Cambridge (MA), 1998), 106, fig. 54, presents the lararium relief from the House of Caecilius Iucundus.

28 For Pompeian imaginaries, see the forthcoming proceedings of the University of Bristol conference, Ruins and Reconstructions. Pompeii in the Popular Imagination, 17-19 July 2007, organized by Shelley Hales and Jo Paul.

29 Such a vast array of material exists in part because boundaries are blurred between the corporate producers of Doctor Who and fans of the programme/phenomenon, who, for example, edit the BBC Doctor Who Magazine and write officially endorsed novels (as the current executive 
least seven times, and once even Pompeii, when Vesuvius explodes. ${ }^{30}$ Alternatively, we might consider how the dynamics established above work for audiences unschooled in the entertainment traditions of the BBC. ${ }^{31}$ The potential reverberations and intertextual readings are endless.

For now, I will put 'The Fires of Pompeii' into the context of its dedicated BBC website (www.bbc.co.uk/doctorwho/s4/episodes/S4_02). As already observed, broadcasters design websites to inculcate loyalty in their audience by offering additional materials and so-called special insights that extend their engagement with the television programme; they also participate in transmedia storytelling that might extend across several platforms. As a consequence, their websites provide a frame for individual programmes that alters the visitor's comprehension of them. ${ }^{32}$ The fruits of the interplay between 'The Fires of Pompeii' and its website have already been witnessed in the analysis above, informed as it is by insights into the writing and production processes presented there. However, because the website provides a platform for exposing its preoccupations and fabrications, it also contributes towards the episode's Roman receptions.

'The Fires of Pompeii' home page is dominated by a central montage. Staring upward and aghast, the Doctor and Donna are superimposed upon a blurry Pompeii street where ash falls on tunic-clad inhabitants; a Sibylline priestess stands to the right and fore, staring at the visitor through eyes painted on her hands as she communicates with the Pyroviles. In the right-hand corner below is another bleary image of the town, now on fire. Across the bottom, the legend 'Some like it hot!' runs at a jaunty angle, followed underneath by the question 'Psychic powers and stone beasts run riot in old

producer, Russel T. Davies, did in Damaged Goods (1996), a New Doctor Who Adventures novel). Fans are also responsible for unsanctioned output, producing fanzines and even videos featuring former Doctor Who actors. As producers and consumers, they are active in shaping the canon as well as responding to it. See A. McKee, 'How to Tell the Difference between Production and Consumption: A Case Study in Doctor Who Fandom', in S. Gwenllian-Jones and R. E. Pearson (eds.), Cult Television (Minneapolis, MN, 2004), 167-85.

${ }^{30}$ In the Big Finish audio adventure The Fires of Vulcan. This and other examples are discussed by L. Parkin, An Unauthorized History of the Doctor Who Universe, second edition (Des Moines, IA, 2007), 50-3.

31 The Britishness of the Doctor and of the series is part of its appeal: see J. Tulloch and M. Alvarado, Doctor Who. The Unfolding Text (New York, 1983). And, for a devastating critique of what happened when its British foundations were overturned in the Anglo-American production Doctor Who: The Movie (1996), see Wright (n. 12).

32 On the shape of broadcaster websites, see S. M. Chan-Olmsted and J. S. Park, 'From On-air to On-line World: Examining the Content and Structures of Broadcast TV Stations' Websites', fournalism and Mass Communication Quarterly 77 (2000), 321-35. 
Pompeii, but can Donna dare the Doctor to change established history?' This pastiche, composed in the style of a 1950s B-movie poster, succinctly introduces the historical setting, the alien intervention that endangers humanity, and the moral conundrum at the heart of the narrative.

These themes are repeatedly addressed in the accompanying videos. On set in the TARDIS, actors David Tennant (the Doctor) and Catherine Tate (Donna) are asked 'The Big Questions': 'This episode is about a famous event in history. If you were given the chance to change history a) would you risk it, and b) which event would you try to change?' The human angle behind this conundrum the destruction of 20,000 ordinary people - is expressly noted (as we have already seen) by Moran in 'Writing the Episode', but also in 'Latest Confidential'. Doctor Who Confidential is a companion documentary that is aired immediately after the show on BBC3. For a week after the broadcast of 'The Fires of Pompeii', an abridged version entitled 'Latest Confidential: The Italian Job' was available on the website; thereafter, it was replaced by a one-minute trailer. In the mid-length version, the producer, Phil Collinson, observes 'this is a story about a whole town of people dying', while the director, Colin Teague, adds 'these were real people. This is a real event on a massive scale.' The priority awarded by the production team to the human angle is reflected in Tennant's observations during a trip to Pompeii. His first response is that 'it's extraordinary how kind of domestic it feels, and how real it feels. You just get the sense of a fully functioning society.' Later, following visits to the Forum, a public bathhouse, and a thermopolium, his guide leads him to the plaster casts of Vesuvius' victims and explains how they were made. The troubled actor observes,

It is always very easy when you think about the historical events for them not to feel particularly human, for them not to feel particularly close. And then you see the shapes of their bodies, and you see how they, how their existence ended, and you can, you can grasp a bit of the story of how appalling, and shocking, and surprising that was.

Tennant's visit to Pompeii, the emphasis on reality, the size of the disaster, and the humanity of its victims draw attention back to the historical setting. The viewer is encouraged to think about the past presented in 'The Fires of Pompeii' as a real past, of the people as real people, and of the event shown as a real episode in human history. 
Yet the 'Latest Confidential' video also emphasizes the fabrication of Doctor Who's Roman world. The 'click to play' frame portrays Tate and Tennant in costume, laughing with the production crew on set in a Roman street. In the opening preview, coming scenes are juxtaposed with close-ups of the production crew and wide-angle shots of the set and costumed actors at leisure. Once the preliminaries are over, Tate explains that cast and crew are in Rome at the Cinecittà studios, which are 'doubling as Pompeii'. As the camera sweeps away, an open space containing temples and similarly 'Roman' structures appears. Yet this Pompeii bears little resemblance to the town later visited by her co-actor. ${ }^{33}$ Moreover, the venues that Tennant visits do not appear in the episode. He does not enter the house of Caecilius Iucundus, or any other domestic structures; of the baths and thermopolium, the latter receives only brief attention in the episode when Caecilius teases his son: 'Where were you last night? Down the thermopolium I bet, cavorting with Christians and Etruscans and all sorts.' Indeed, on arrival Donna and the Doctor cannot distinguish the streets of Pompeii from the Roman cityscape: it is the looming volcano that identifies the city.

Thus, while Tennant's visit historicizes Pompeii, the Pompeii of the television programme is very much still a set. This is emphasized again in the shorter 'Confidential Trailer'. Here conversations about reality are replaced by more on-set footage, although allusions to history remain: the viewer is invited to 'witness a blast from the past' and later (in homage to another BBC sitcom) to follow David Tennant ' $U p$ Pompeii!' and up a still-smoking Vesuvius. The fictionality of the show is even more upfront in other videos. In 'Phil Collinson', the producer leads the cameras into the Cinecittà costume store to find helmets, wigs, and boxes overflowing with sandals provided by the studio. The 3D supervisor Jean-Claude Deguara demonstrates how the Pyroviles were generated on computer in 'Making the Pyroviles'. And the actors who play Caecilius and Metella are interviewed in costume, on-set at the family home, for 'Peter Capaldi and Tracey Childs'. While Childs talks about her character, a busy crew are at work behind her. And when Capaldi discusses how one can observe the set coming together through camera monitors, the camera pans across the interior of a house last

33 This is not surprising because the city of Rome provided the inspiration for the Rome sets: see M. S. Cyrino, 'Introduction' in Cyrino (n. 9), 2-3. 
seen, albeit with alternative décor, in Rome. Childs herself remarks, 'You kind of feel like you're doing the BBC series Rome.'

With their insights into the production process, the interviews hosted on the website inform the audience that the historicity of the setting is vital to the narrative, while also revealing how that historical setting was fabricated. In 'The Fires of Pompeii', history and fiction are grafted together; on the episode website, their fault-lines are freely exposed. Yet these platforms work in tandem. Where the episode advances the Doctor's dilemma by shaping Rome/Pompeii into familiarly historical places and people, the website prioritizes the crafting of Pompeii as a means of accessing a historical event and society. Like David Tennant wandering the ruins of Pompeii, the viewer/visitor is confronted with the humanity of the long-dead community. Although accuracy in historical detail is never a stated agenda, the comprehension of history through emotional engagement stands to the fore.

The interplay between history and fiction is given an additional twist in 'The Monster Files', a mock-documentary hosted by Captain Jack (John Barrowman), the hero of the Doctor Who spin-off, Torchwood. It presents 'evidence recently unearthed' that enables us to 'at last work out what happened' at Pompeii. ${ }^{34}$ This new evidence is a video shot in 1923 by Professor Livesy-Smyth of the British Archaeological Survey of Rome, detailing the discovery of a scroll written by Caecilius. Found (as the grainy black-and-white silent footage reveals) alongside a curiously cut marble square, the scroll tells of Pompeii's final days: the story of 'The Fires of Pompeii'. This pseudo-historical footage is interspersed with scenes from the episode and glimpses of the illustrated manuscript, overcut by Captain Jack's narrative, so that the story unfolds in the tradition of contemporary historical documentary, the television docudrama (or dramatized documentary). Further evidence follows: a monstrous footprint melted into a mosaic at Pompeii, unexplained marble sculptures, and 'this intriguing plaque showing the family gods of the Caecilius family'. In this retelling, props from the set - the Pyrovile circuit board and the Doctor-and-Donna lararium relief - are testimony to the events reconstructed in 'The Fires of Pompeii'. Finally, following scenes of Vesuvius exploding and Pompeii burning, Captain Jack concludes, 'with findings unearthed by carefully monitored archaeological excavations it can't be denied. The discoveries are irrefutable.' The reality AD 79 .

34 Bizarrely, in the opening sequence the event is located in the first century $\mathrm{BC}$, rather than 
of 'The Fires of Pompeii' no longer lies in the explosion of Vesuvius and human experience, but in the story itself. Yet, as in any good mock-documentary, the fictionality of its narrative constructions is played with throughout. ${ }^{35}$ Interspersed with the dramatized shots are placards reading 'Reconstruction', 'Made using special photographic trickery', and 'Simulated speculation'. The episode is a historical reconstruction, based on historical events, but it is still a fabrication. This mischievous pastiche of early film, posed archaeological investigation, and explicit fictionalizing follows the direction laid out by the writing team and production crew: again through televisual intertextuality, ancient Rome/Pompeii emerges as both a historical space and a crafted reconstruction.

\section{Crafting Rome from television to history}

The combination of history and fiction in modern depictions of antiquity is not unique to 'The Fires of Pompeii' ${ }^{36}$ Television reconstructions of ancient Rome repeatedly prioritize their historicity. In $I$, Claudius (BBC, 1975), for example, the message of moral degeneracy and power required a convincing historical setting to emphasize the dangers that beset the modern world. ${ }^{37}$ Authenticity also lends Rome validity: 'A serialized drama of love and betrayal, masters and slaves, husbands and wives, Rome chronicles the epic times that saw the fall of the Republic and creation of an empire' ${ }^{38}$ Rome's story is history: the history of the Republic and the history of ordinary Romans. ${ }^{39}$ This ambition is shared by another BBC production, Ancient Rome: The Rise and Fall of an Empire (2006). Combining lavish sets and dramatic narratives with an authoritative voice-over, this 'dramatized

35 According to J. Roscoe and C. Hight, Faking It. Mock-documentary and the Subversion of Factuality (Manchester and New York, 2001), 52-3, the mock-documentary uses the techniques of dramatized documentary in order to expose the fictionalities that the latter genre seeks to elide (see also n. 40, below).

${ }^{36}$ M. M. Winkler, 'Gladiator and the Traditions of Historical Cinema', in Gladiator. Film and History (Oxford, 2004), 17, notes: 'Films are by necessity a mixture of fact and fiction. The same is true for any kind of re-creation of any era of the past in any medium.' For another take on history in film, see T. Harrison, 'Oliver Stone, Alexander and the Unity of Mankind', in F. Greenland and R. Lane Fox (eds.), Responses to Alexander (Cambridge, forthcoming).

37 S. R. Joshel, 'I, Claudius: Projection and Imperial Soap Opera', in Joshel, Malamud, and McGuire (n. 5), 150.

38 Rome. The First Complete Series (2006): DVD sleeve.

39 For the commitment of Rome's production team to authentic detail, see K. Milnor, 'What I Learned as an Historical Consultant for Rome', in Cyrino (n. 9), 42-8; and on its pursuit of history, see W. J. Tatum, 'Making History in Rome: Ancient vs Modern Perspectives', in Cyrino (n. 9), $29-41$. 
documentary' adopts the mechanisms of television (its sets, costumes, and CGI reconstructions, as well as the story-patterns of Rome) to tell, once more, 'the true story of Rome'. ${ }^{40}$ Thus, despite their differing topics, formats, and agendas, each programme invests its authority in its authentic portrayal of history. 'The Fires of Pompeii' does this too, but in that episode the 'historical reality' is explicitly televisual, and contributes towards a Doctor Who story of humanity, morality, and aliens, not the presentation of truths about the past. Moreover, while the historical dramas elide their fictions, the online revelation of fabrications enhances awareness and understanding of the dynamic interplay between history and fiction in 'The Fires of Pompeii'. ${ }^{41}$

The utility to the modern historian claimed for televisual and cinematic representations of ancient Rome usually centres on their revelation of contemporary preoccupations and discourses about the past, or their provision of an approximation of what life may have been like. ${ }^{42}$ Yet, because of the ambiguity and openness of its relationship to the past, 'The Fires of Pompeii' - viewed as a televisual event and read through the Doctor Who website - is an excellent starting point for thinking about how historians, as well as television production companies, reconstruct antiquity. Often in the popular media (including the dramas discussed above), history is 'what happened' and historical investigation or representation aims to discover the 'truth' ${ }^{43}$ But, for the professional historian, the past is a fragmented

40 Ancient Rome. The Rise and Fall of an Empire (2006): DVD sleeve. For similarities to Rome, listen to the authorial monologue that opens episode 1, over shots of conflict in battle and a very familiar city. The narrator promises that the rise and fall of the Roman empire will be told from the perspective of great events, stories of love and betrayal, and personalities. The series' claims to truth-telling and historical reflection in the advertising material and programme content belie documentary makers' awareness of the contentious nature of their truths, which are necessarily fictive and constructed through artifice: see M. Renov, 'Introduction: The Truth about Non-fiction', in M. Renov (ed.), Theorizing Documentary (New York and London, 1993), 1-11, and J. Ellis, 'Documentary and Truth on Television: The Crisis of 1999', in A. Rosenthal and J. Corner (eds.), New Challenges for Documentary, second edition (Manchester and New York, 2005), 342-60. De Groot (n. 6), 149-54, unpacks some of the implications of this ambivalence for historical documentary in particular. Dramatized documentaries such as Ancient Rome. The Rise and Fall of an Empire are particularly implicated in the anxieties: see J. Corner, 'British TV Dramadocumentary: Origins and Developments', in A. Rosenthal (ed.), Why Docudrama? Fact-Fiction on Film and TV (Carbondale, IL, 1999), 35-46.

${ }^{41}$ Tellingly, visitors to Rome's website are invited 'Behind the Scenes' 'for a close-up look at the rich tapestry of artifacts and designs that made up the backdrop of Roman life', and at 'authentically recreated props': <http://www.hbo.com/rome/behind/>, accessed 8 January 2009. The sense of fun and irreverence that marks Phil Collinson's foray into the Cinecittà costume department is entirely absent.

42 See Wyke (n. 5), 12-13; Cyrino (n. 33), 7; Winkler (n. 36), 17.

43 This tendency is apparent in television programmes of different origins, but the recent output of the BBC is revealing. In The Dream of Rome (2006), Boris Johnson, the classically 
and ephemeral space, the product of diverse literary and pictorial narratives, which changes as the narratives, shaped by their production contexts, shift and combine in different ways. In other words, our past is a reconfiguration of earlier refractions of that past, whether filtered through scholarship or ancient writing, images, and archaeological remains. It is also circumscribed by our research agenda, the pursuit of specific questions, and the ignorance of others. In this respect, as academic critiques of Rome have recently stressed, the historian is not dissimilar to the television producer who uses her sources - general knowledge of antiquity and recent representations of it - to construct a narrative of the past matching a specified agenda. ${ }^{44}$ Nor is she hugely different from the authors, painters, and sculptors of antiquity responsible for the evidence we now use. ${ }^{45}$ No source provides an unmediated access to the truth; each filters the material of its discussion through the viewer's own experiences and agendas. To this end, 'The Fires of Pompeii', with its televisual and literary intertextualities and online deconstructions, offers an engaging reminder of the processes of historical construction and of the fictionality of our own historical Rome.

educated Oxonian politician (now Mayor of London) and media personality, sought to demonstrate how the Romans ran their empire and then used this as a measure for the failure of the European Union. The BBC Ancient History website also offers another neat example, with its opening tag-line: 'Mad emperors, brutal entertainments and lascivious lifestyles. These are the familiar images of ancient Rome, but what was it really like?': <http://www.bbc.co.uk/history/ ancient/romans/>, accessed 8 January 2009. This positivist approach to historical inquiry online might be linked to the documentary habits that characterize the Information Age, to which the internet belongs: see R. E. Day, 'The Erasure and Construction of History for the Information Age: Positivism and its Critics', in L. Rabinovitz and A. Geil (eds.), Memory Bytes. History, Technology, and Digital Culture (2004), 76-96.

${ }^{44}$ For this theoretical perspective, see H. White, 'The Fictions of Factual Representation', in D. Preziosi and C. Farago (eds.), Grasping the World. The Idea of the Museum (Aldershot, 2004), 22: 'history is no less a form of fiction than the novel is a form of historical representation'. Cf. Milnor (n. 39), 44-5.

45 Noted by Tatum (n. 39), 39, not entirely with favour. 